\title{
Assessment of the visual landscape quality based on the subjectivist paradigm to design the memorial garden
}

\author{
Sahar Pouya ${ }^{a, *}$, Homa Irani Behbahani ${ }^{a}$
}

\begin{abstract}
Assessment of the visual landscape quality is a core part of studies in landscape and urban projects. The landscape visual assessment has been carried out on the basis of two paradigms; objectivist and subjectivist paradigms. This research is a case of landscape evaluation based on the subjectivist or psychological paradigm. The purpose of the research is to understand the beholder's perception of the visual quality of landscape and to use it in the design of a war memorial garden. In this article, three main holistic concepts formed during the war (war between Iran and Iraq) are determined, and then seniors majoring landscape architecture were asked to define these concepts for each the landscape elements. Then three dominant views of the site were scored according to the students' perceptions and finally zoning of the site was proposed. This article emphasizes on the perception- based approaches in landscape studies and the opportunities that the current landscape of the site may have in order to imply the specific concepts. To design a symbolic or memorial place, the perceptions conveyed by the visual elements of the landscape have impressive role in making decision about the land uses and will lead to a more sustainable and dynamic memorial spaces.
\end{abstract}

Keywords: Subjectivist paradigm, Memorial garden, Visual landscape quality

\section{Anıt bahçesinin tasarlanması için öznelcilik paradigmasına dayalı görsel peyzaj kalitesinin değerlendirilmesi}

\begin{abstract}
Özet: Görsel peyzaj kalitesinin değerlendirilmesi, peyzaj ve kentsel projelerde yapılan çalışmaların temel bir parçasıdır. Peyzaj görsel değerlendirmesi iki paradigma temelinde yürütülmüştür; nesnelci ve öznelcil paradigmalar. Bu araştırma, öznelci veya psikolojik paradigmaya dayalı bir peyzaj değerlendirmesi örneğidir. Araştırmanın amacı, seyirci açısından manzara görsel kalite algısını açıklamak ve onu anıt bahçe tasarımında kullanmaktır. Bu yazıda, savaş sırasında (İran ve Irak savaşı) oluşan üç temel bütünsel kavram belirlenmiş ve daha sonra peyzaj öğeleri için bu kavramları tanımlamaları, son sınıf öğrencileri, peyzaj mimarlığı bölümünden istenmiştir. Daha sonra öğrencilerin algılamalarına göre sitenin üç hakım görünümü derecelendirildi ve nihayet alanın imar edilmesi önerilmiştir. Bu makale, peyzaj çalışmalarında algı tabanlı yaklaşımlara ve sitenin mevcut manzarasının spesifik kavramların kullanılması açısından sahip olabileceği firsatlara vurgulamıştır. Bir sembolik veya anıtsal mekanın tasarlanması için, arazi kullanımları hakkında ve karar vermede manzara görsel öğelerinin aktardığı algılamalar, etkileyici bir role sahiptir ve daha sürdürülebilir ve dinamik bir anıt alanına neden olacaktır.
\end{abstract}

Anahtar kelimeler: Öznelcil paradigma, Anıt bahçesi, Görsel peyzaj kalitesi

\section{Introduction}

Studies of the landscape quality are the secondary part of primitive studies before doing design, and nowadays draw much attention from designers of the environment. Landscape visual assessment is a main component of landscape architecture, landscape planning and various studies in decision process. There are different approaches for assessing the scenic qualities of landscapes developed in the last few decades (Wu et al., 2006). It provides clear data of the landscape structure as such as land form, color, water surface and green elements (Tveit et al., 2006) and also allows the integration of local perception towards the surrounding and creates a sense of belonging and identity in any of future planning development (Rosley et al., 2013).
Landscape quality assessment divided into two core categories known as objectivist (expert approaches) and subjectivist (community perception-based approach) (Terry, 2001). Two contracting paradigms differ from one another based on the different angle of one's in assessing the environment.

\section{Objective Approach (expert-design approach)}

In the objectivist/physical paradigm, the landscape visual quality is defined by biological and physical values. It stresses viewing the environment as intrinsic attribute of the physical qualities and regards quality also as a product of the mind-eye of beholder. In this way, the quality of landscape is usually assessed by using criteria for landscape.

\footnotetext{
a Environmental Design College, Iran, 51368, Tehran, Azin Alley, Gods st., Enghelab Ave., University of Tehran

Corresponding author (İletişim yazarı): pouya@itu.edu.tr

$\checkmark \quad$ Received (Geliș tarihi): 24.02.2017, Accepted (Kabul tarihi): 19.07.2017
}

Citation (Atıf): Pouya, S., Behbahani, H.I., 2017. Assessment of the visual landscape quality based on the subjectivist paradigm to design the memorial garden. Turkish Journal of Forestry, 18(3): 171-177. DOI: $10.18182 /$ tjf.294916 
Subjective Approach (perception-based approach)

The perception-based approach or the subjective paradigm emphasizes the human view of the landscape (Wu et al., 2006). This paradigm considers that landscape quality derives from the eyes of beholder. So this paradigm is more complicated as it involves the interpretation of one's perception based on their background and associated experiences (Lothian, 1999).

Some researchers believe that assessing the visual quality of landscape should be a subjective task, as ecological and visual-based criteria are needed for explaining the main features of the landscape to increase the objectivity (Fry et al., 2009). Gobster, (1999) argued that landscape quality should be extended beyond perceptual, which is based on cognitive, experiential and knowledge based (subjectivist). However, Jessel (2006) mentions that methods for registering visual qualities are partly based on a description of landscape attributes (various types of vegetation and attributes of landscape structure) and are also based on landscape characteristics (the typical order of attributes in landscape scenery, their shape and proportion).

Main studies have been performed about landscape perception so far. Zube et al.'s (1982) landscape perception framework has developed a rich source for understanding the aesthetic experience of landscapes, and created a renewed attention in the context of ecological aesthetics. The best known landscape perception research has been done by the Kaplans (1989). They believe that humans have needs to know the world that surrounds us. Paul H. Gobster (1999) has also studied on how people perceive and experience parks and forests, including issues of aesthetics, psychological restoration, and physical activity. He has differentiated scenic beauty from ecological aesthetic.

\section{Memorial Gardens}

Memorial sites are "Garden of remembrance is a public place designed and designated as a focal point for specific memory; some gardens have been located over the site of a particular tragedy" (Gough, 2000). The culture of remembrance is a common attribute in our common understanding of war memorials and their landscapes. There were fulfilled varieties of symbolic functions in the landscape of memorial gardens to covey the specific values, concepts and memories. The Holocaust Memorial to the Murdered Jews, a symbolic cemetery with unique cubic forms was established in which the landscape elements have conceptual functions. Similarly, in the memorial gardens of 11 September, that is located at the site of the former Twin Towers, the memorial features are two huge waterfalls and reflecting pools that aim to convey a spirit of hope and renewal, and acts as memories of the victims (Pouya, 2011). However the visitors' perceptions of the landscape have been evaluated neither before project nor after that. To answer the question whether the symbolic landscapes performed in the gardens could be perceived by the visitors, this article focuses on the victors' perception of signs and symbols through visual landscape assessment.

War memorials have valued as national and civic memory that carries holistic concepts for a nation experienced the tragedy (Ahmadi, 1992). This article illustrates a landscape assessment based on the subjectivist paradigm with the aim of creating a memorial garden. Since the war memorial gardens are intended to imply a number of events and concepts for the beholders (Yung, 1980), in this research, the study of landscape is conducted to comprehend the implicit concepts of landscape in the mind of the viewer.

The war memorial garden tries to remind special events occurred in the past. Thus, some signs and symbols are needed to imply a number of concepts and events (Pouya, 2011). In other words, it is necessary to evaluate the current landscape based on how much it can imply the signs and symbols of a specific event for the visitors. So first of all, in the step of the landscape analysis, it has been recognized the visual signs and symbols related to the war (in this case the war between Iran and Iraq in 1978) in the site based on the people and beholder's perspectives.

\section{Methods}

In this study, the assessment of landscape quality is not aimed to assign a beautiful landscape in the mind of beholder, but it tries to assess the landscape and views of the site. In this work, the perception-based approach is used for evaluation the landscape of the site. The steps which are followed in this work are respectively:

First; the main variables of the landscape including (Earth's structure, Topography, Water, Vegetation, manmade structures and depth of view) are defined as tables.

Second; the concepts related to the event (war between Iran and Iraq as case study) through the evidence, documents and other sources are assigned and illustrated.

Third; the specific signs and symbols related to the event for each of the landscape variables are determined based on the perceptions of the students studying in landscape architecture. 35 senior students in department of landscape architecture at University of Tehran are interviewed and their view points are categorized as tables.

Fourth, the pictures of dominant views of the site (three views) are provided and then scored based on the definite criteria by the students for each visual landscape elements. The highest and lowest scores are considered to be 4 (ideal) and -3 (very unpleasant). These scores are given for different degrees of symbolic and symptomatic levels in the photographs. The scores and results of the assessment are presented as tables in this work.

Finally, it is decided about the various zone of site (zoning).

\section{Materials}

In this study, the site that was considered to assess the quality of landscape is the east-west hill at the entrance of the city of Tabriz, Iran (Figure 1). The hill, at the height of 1600 meters above sea level, has a visual relationship with the urban fabric and the northern mountains located in the west and south of the city (Halali, 2006). In this study, three dominant views are selected from the hill to its surroundings in the north, south and west (Figure 2). 


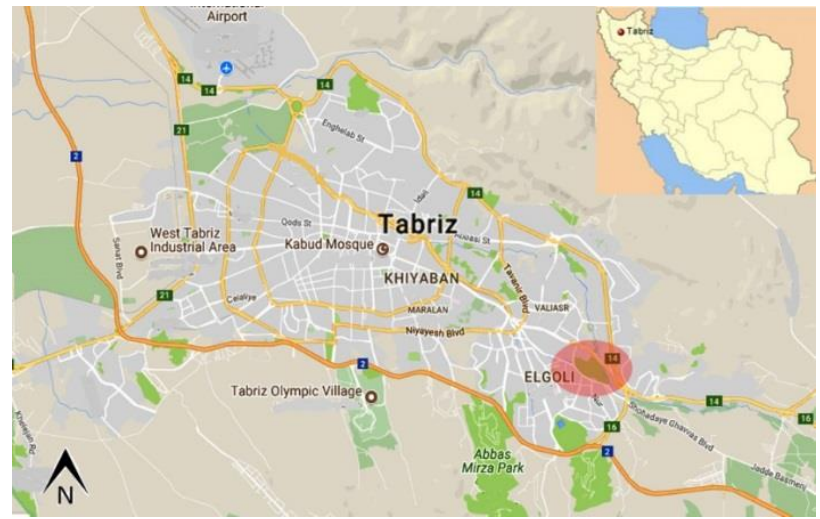

Figure 1. Location of the site in the city of Tabriz/Iran

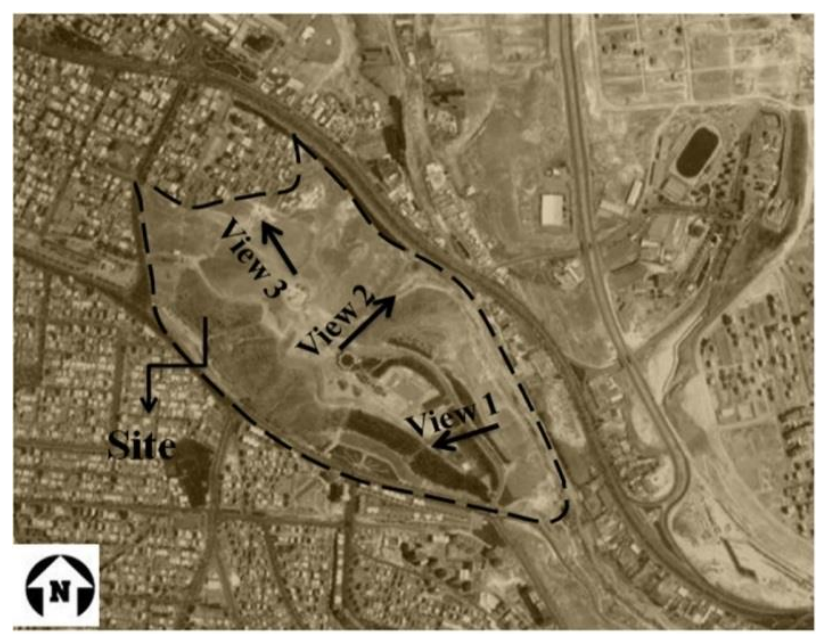

Figure 2. Directions of chosen views of the hill for the landscape quality evaluation

\subsection{Defining the valuable concepts of war for the memorial garden}

According to the classification of Nohl (2001), which was proposed on the basis of aesthetic perception of landscape, there are at least four different levels of aesthetic cognition (i.e., expressive, perceptual, symbolic and symptomatic), by which a beholder may get specific information or concepts (c.f. Nohl, 1980). At the expressive level of aesthetic cognition, all the perceived elements and structure are associated with the feeling and emotion of beholder. At the perceptual level, the beholder of landscape immediately gains the relevant information through the senses (e.g. by seeing, hearing or smelling).

However, at the symbolic and symptomatic levels of aesthetic cognition, which were addressed in this study, visible objects in landscape also indicate and refer to something else. At the symptomatic level, however, the contents attached to the indicating or symbolizing objects are not the realities of landscape as they are. Here, they are developed as ideas, imagination and utopian pictures, which are generated in the mind of viewer. At the symptomatic level, objects are understood as signs or symptoms indicating the objects that are beyond themselves (Figure 3 ).
The memorial garden is a place that needs to use a number of symbols and signs to depict and imply the concepts pertinent to a special adventure or event in the mind of beholder. Therefore, in the quality assessment and aesthetic perception of landscape, efforts should be made to assess the landscape of site on the basis of the signs and symbols included in the landscape.

This research tries to assess the landscape quality of the site in order to design a war memorial garden in Tabriz, Iran. It is assumed that the garden should remind the valuable concepts related to the war between Iran and Iraq that lasted eight years. This war was suddenly started in 1978, during which there is no alternative for the Iranian people but to resist and oppose the enemy (Pouya et al., 2014). During the years of Iranian resistance, profound concepts have been discerned, which were subsequently depicted in the works of art (Ghazizadeh, 2010). Concepts such as the unity of people, defense and resistance against the enemy, sacrifice, hope and reconstruction after the war have been the definitive and noticeable notions of the war that are valuable to remind and imply (Taghi Zadeh, 2008; Palangi, 2008).

In this research, three principal concepts of resistance, unity, and reconstruction are chosen to remind in the memorial garden. In the aesthetic perception of landscape, the concept of reconstruction for the symptomatic level; and the concepts of resistance and unity for the symbolic level have been considered.

\subsection{Defining the concepts in visual and physical elements of landscape}

After the three concepts of the war were determined, they must be defined as symbols and signs for each of the physical elements of landscape. To do this, 35 seniors majoring landscape architect were asked to define symbols of the concepts of resistance and unity as well as signs of the concept of reconstruction in visual landscape. For instance, the students were asked to answer questions like which form of water (running or still) can be a symbol for the concept of resistance? Which texture of tree or shrub can be a symbol for the concept of unity? Or which color of instructions can be a sign for the concept of reconstruction? The collected comments and answers are summarized in the Tables 1, 2 and 3.

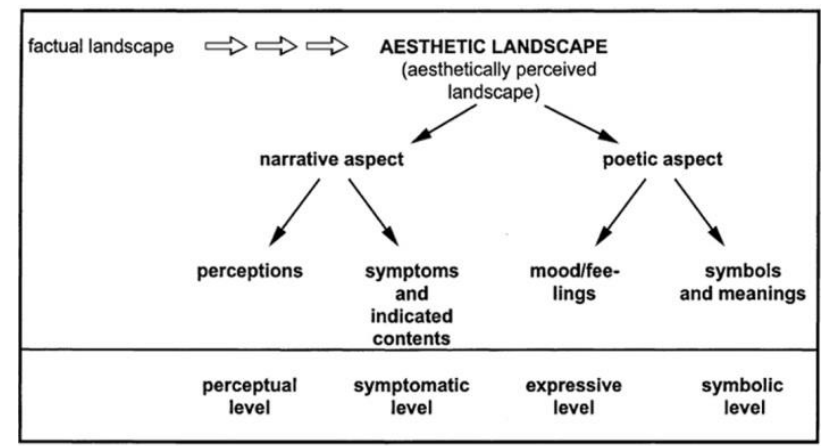

Figure 3. Aesthetic perception of Landscape and level of aesthetic cognition (Nohl, 2001) 
Table 1. Definition of symbols for the concept of resistance in each of the visual elements of landscape, according to students majoring in landscape architecture

\begin{tabular}{|c|c|c|c|}
\hline \multicolumn{3}{|c|}{ Visual elements of landscape } & Symbols of the resistance concept \\
\hline \multirow{5}{*}{$\begin{array}{l}\text { Natural } \\
\text { elements }\end{array}$} & \multirow{4}{*}{$\begin{array}{l}\text { Physical } \\
\text { elements }\end{array}$} & $\begin{array}{c}\text { Earth's } \\
\text { structure }\end{array}$ & $\begin{array}{l}\text { Natural and pyramidal landforms, hard materials of concrete, stone, or asphalt, as well as the } \\
\text { colors darker than that of the land can be symbols of the concept of resistance. }\end{array}$ \\
\hline & & Topography & $\begin{array}{l}\text { High height of land besides the low-slope or flat surfaces can be a symbol for the concept of } \\
\text { resistance. }\end{array}$ \\
\hline & & Climate & $\begin{array}{l}\text { Blowing extremely of wind at the surfaces and elements of landscape resisting, and sometimes } \\
\text { high and dark shadows of elements may be considered symbols for the concept of resistance. }\end{array}$ \\
\hline & & Water & $\begin{array}{l}\text { The still water, deep water, and light water may be considered symbols for the concept of } \\
\text { resistance. }\end{array}$ \\
\hline & $\begin{array}{l}\text { Biological } \\
\text { elements }\end{array}$ & Vegetation & $\begin{array}{l}\text { The pyramidal or flat forms, rough and fine textures, condensed vegetation or serially semi- } \\
\text { condensed vegetation, tall plants, and older plants may be considered symbols for the concept of } \\
\text { resistance. }\end{array}$ \\
\hline \multirow{2}{*}{$\begin{array}{l}\text { Physical } \\
\text { elements }\end{array}$} & & Path (road) & $\begin{array}{l}\text { Curved shapes, as well as long narrow path paved with stone, concrete or asphalt may be } \\
\text { considered symbols for the concept of resistance. }\end{array}$ \\
\hline & & Housing & $\begin{array}{l}\text { Square and symmetrical forms, old urban structures among moderns ones, and dim tall building } \\
\text { may be considered symbols for the concept of resistance }\end{array}$ \\
\hline \multicolumn{3}{|c|}{ Depth of the View } & Semi- limited view to horizon may be symbols of the resistance concept. \\
\hline
\end{tabular}

Table 2. Definition of symbols for the concept of unity in each of the visual elements of landscape, according to students majoring in landscape architecture.

\begin{tabular}{|c|c|c|c|}
\hline & & Visual elements of landscape & Symbols of the unity concept \\
\hline \multirow{5}{*}{$\begin{array}{l}\text { Natural } \\
\text { elements }\end{array}$} & \multirow{4}{*}{$\begin{array}{l}\text { Physical } \\
\text { elements }\end{array}$} & Earth's structure & $\begin{array}{l}\text { Structures congruous in color, material and landform can be symbols for the } \\
\text { concept of unity. }\end{array}$ \\
\hline & & Topography & $\begin{array}{l}\text { Average height with a gentle slope of land can be regarded as symbols for the } \\
\text { concept of unity. }\end{array}$ \\
\hline & & Climate & $\begin{array}{l}\text { Mild temperature and breeze besides desired light can be regarded as symbols } \\
\text { for the concept of unity. }\end{array}$ \\
\hline & & Water & $\begin{array}{l}\text { Less flowed wave of water between the surfaces having the edges coordinated } \\
\text { with the surroundings can be regarded as symbols for the concept of unity. }\end{array}$ \\
\hline & $\begin{array}{l}\text { Biological } \\
\text { elements }\end{array}$ & Vegetation & $\begin{array}{l}\text { The existing evergreen species besides deciduous species, in any three classes } \\
\text { of trees, shrubs and bushes, in different seasons can be regarded as symbols for } \\
\text { the concept of unity. }\end{array}$ \\
\hline \multirow{3}{*}{$\begin{array}{l}\text { Physical } \\
\text { elements }\end{array}$} & & Path (road) & $\begin{array}{l}\text { Structures with straight or curved paths can be regarded as symbols for the } \\
\text { concept of unity. }\end{array}$ \\
\hline & & Housing & $\begin{array}{l}\text { Harmonic mixture of buildings and vast forms, circular forms, or square forms } \\
\text { of building enclosed by circular yards can be regarded as symbols for the } \\
\text { concept of unity. }\end{array}$ \\
\hline & \multicolumn{2}{|c|}{ Depth of the View } & $\begin{array}{l}\text { Open view to the horizon, as opposed to closed view can be regarded as } \\
\text { symbols for the concept of unity. }\end{array}$ \\
\hline
\end{tabular}

Table 3. Definition of signs for the concept of reconstruction in each of the visual elements of landscape, according to students majoring in landscape architecture.

\begin{tabular}{|c|c|c|c|}
\hline \multicolumn{3}{|c|}{ Visual elements of landscape } & Symbols of the reconstruction concept \\
\hline \multirow{5}{*}{$\begin{array}{l}\text { Natural } \\
\text { elements }\end{array}$} & \multirow{4}{*}{$\begin{array}{l}\text { Physical } \\
\text { elements }\end{array}$} & Earth's structure & $\begin{array}{l}\text { Light earth and man-made forms (excavations and earthwork) can be signs for the } \\
\text { concept of reconstruction. }\end{array}$ \\
\hline & & Topography & $\begin{array}{l}\text { Rising ground with an average slope or the forms changed by man can be signs } \\
\text { for the concept of reconstruction. }\end{array}$ \\
\hline & & Climate & Extremely light and shade spaces can be sign for the concept of reconstruction. \\
\hline & & Water & $\begin{array}{l}\text { Bright blue water with roaring sound can be signs for the concept of } \\
\text { reconstruction can be sign for the concept of reconstruction. }\end{array}$ \\
\hline & $\begin{array}{l}\text { Biological } \\
\text { elements }\end{array}$ & Vegetation & $\begin{array}{l}\text { Short plants, serial and regular vegetation, desired distribution of plants in each } \\
\text { class, young plants, medium texture, and floral plants can be signs for the concept } \\
\text { of reconstruction. }\end{array}$ \\
\hline \multirow{2}{*}{$\begin{array}{l}\text { Physical } \\
\text { elements }\end{array}$} & & Path (road) & $\begin{array}{l}\text { Round-about path with arranged sidewalks of different colors can be signs for the } \\
\text { concept of reconstruction. }\end{array}$ \\
\hline & & Housing & $\begin{array}{l}\text { Colored buildings with modern architecture and various materials can be signs for } \\
\text { the concept of reconstruction. }\end{array}$ \\
\hline \multicolumn{3}{|c|}{ Depth of the View } & $\begin{array}{l}\text { Partially limited view with broken horizon lines can be signs for the concept of } \\
\text { reconstruction. }\end{array}$ \\
\hline
\end{tabular}




\section{Results: Scoring the pictures}

The visual elements of pictures that are selected from three views of the hill (Figures 4, 5,6) are scored in this step according to the criteria defined in the Tables 1,2 and 3 by the students. In scoring the pictures of the three views, highest and lowest scores are considered to be 4 (ideal) and -3 (very unpleasant) according to the Table 4 .

The scores are given for different degrees of symbolic and symptomatic levels in the photographs. The results of the views assessment are presented as weak, too weak and good for each concept and perception in the Table 5.

It can be inferred from the table 5 that the view 1 (Figure 4) has more symbols of reconstruction concept in comparison with the two other views. The view 2 (Figure 5) includes strong symbols for the concepts of resistance and unity and has weak signs for the concept of reconstruction. The concept of resistance in the view 3 (Figure 6) has more understandable symbols than the two other concepts.

According to the analyses and the quantity of the landscape's signs and symbols, the primary zoning of the site for the war memorial garden design can be proposed. The zone 1 including the view 1 (view to southern landscape) can be considered as a place for implying the concept of reconstruction after the war between Iran and Iraq. Zone 2 with the view of northeast landscape and the symbols of unity can be considered a place for implying the concept of unity demonstrated by the Iranian people during the war period. Similarly, zone 3 having the symbols of resistance more than other signs can be considered a place that implies the concept of resistance in the best way (Figure 7).

Landscape is full of signs and symbols that remind the people about various feelings and concepts. The current visual landscape of the site can create some opportunities and possibility that help the planner or designer catch the goal. This work has focused on finding specifically visual signs in the site and its surrounding which may remind the viewers about the event happened 35 years ago. By the subjective approach used in this work, the designer is able to decide better about the location each conceptual space over the site. Landscape zoning as the main step of any design projects can be provided based on the intrinsic perceptions and concepts of the site itself. In fact, this approach can somehow guarantee that target concepts of the planners or the designers are understood and perceived through project.

Table 4. Assignment degrees of desirability

\begin{tabular}{lc}
\hline Degrees of landscape desirability & X: Elective concept \\
\hline Great (excellent) & $2<\mathrm{X} \leq+4$ \\
Pleasant (good) & $0<\mathrm{X} \leq 2$ \\
Unpleasant (weak) & $-1<\mathrm{X} \leq 0$ \\
Very unpleasant (too weak) & $-3<\mathrm{X} \leq-1$ \\
\hline
\end{tabular}

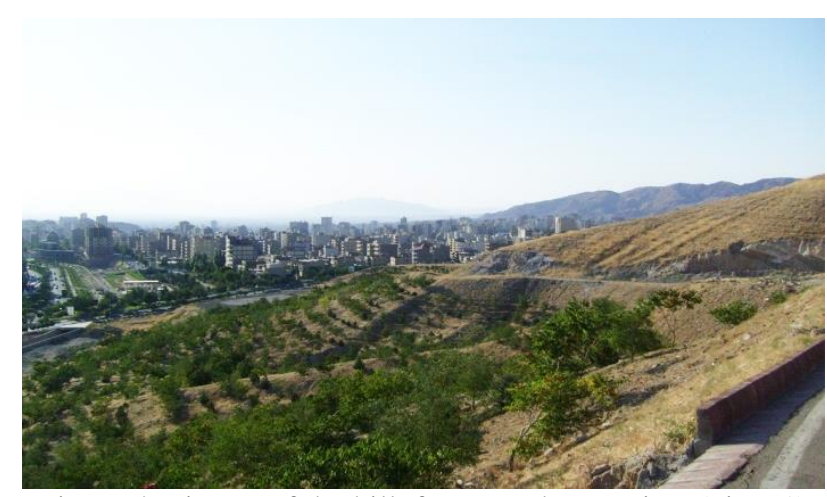

Figure 4. Picture of the hill from southwest view (view 1)

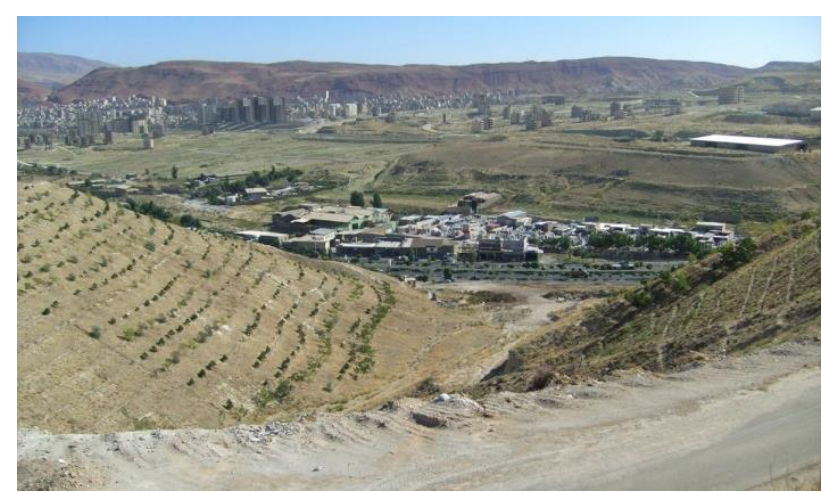

Figure 5. Picture of the hill from its northeast view (view 2)

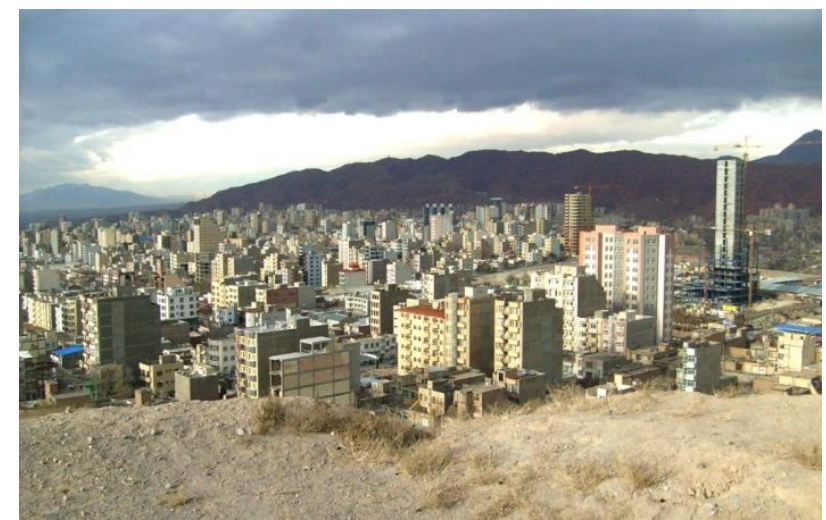

Figure 6. Picture of the hill from its west view (view 3)

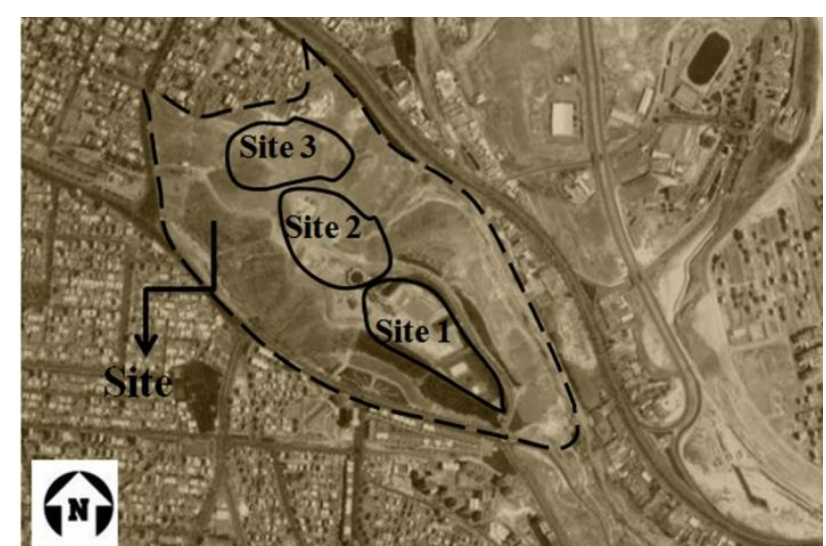

Figure 7. Landscape zoning of the hill; (picture by authors) 
Table 5. Scoring of signs and symbols in the pictures of views 1, 2 and 3

\begin{tabular}{|c|c|c|c|c|c|c|c|c|c|c|}
\hline \multirow{2}{*}{\multicolumn{2}{|c|}{$\begin{array}{l}\text { Visual elements of } \\
\text { landscape }\end{array}$}} & \multicolumn{3}{|c|}{ View 1 (Picture 1) } & \multicolumn{3}{|c|}{ View 2 (Picture 2) } & \multicolumn{3}{|c|}{ View 3 (Picture 3) } \\
\hline & & 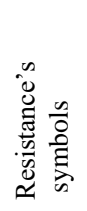 & $\begin{array}{l}n \\
0 \\
0 \\
\vdots \\
\infty \\
\infty \\
0 \\
\vdots \\
\vdots \\
0\end{array}$ & 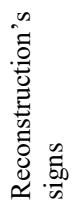 & 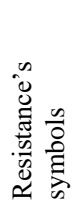 & $\begin{array}{l}n \\
0 \\
0 \\
\vdots \\
\infty \\
\infty \\
0 \\
\vdots \\
\vdots \\
\vdots\end{array}$ & 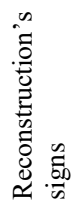 & 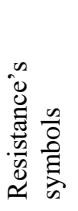 & 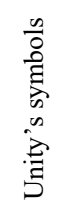 & 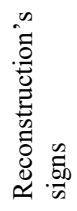 \\
\hline \multirow{5}{*}{$\begin{array}{l}\text { Natural } \\
\text { elements }\end{array}$} & Earth's & +.5 & -3 & +.5 & +1 & +3 & 0 & +1 & 0 & +1 \\
\hline & structure & +2 & +2 & +1 & +3 & +3.5 & -.5 & 0 & 0 & 0 \\
\hline & Topography & 0 & 0 & +.5 & +1 & +1 & 0 & +1 & +.5 & -1 \\
\hline & Climate & 0 & 0 & -4 & -1 & 0 & -4 & 0 & 0 & 0 \\
\hline & $\begin{array}{l}\text { Water } \\
\text { Vegetation }\end{array}$ & -2 & -1 & +3 & +1 & -2.5 & +.5 & -.5 & 0 & -3 \\
\hline \multirow{2}{*}{$\begin{array}{l}\text { Physical } \\
\text { elements }\end{array}$} & Path (route) & -1.5 & +3 & 0 & 0 & +1 & -2 & +.5 & 0 & -2 \\
\hline & Housing & +.5 & +1 & +2 & +1.3 & +3 & -2 & +.2 & +2.5 & +3 \\
\hline \multirow{2}{*}{\multicolumn{2}{|c|}{$\begin{array}{l}\text { Depth of the View } \\
\text { Average }\end{array}$}} & 0 & -4 & +1.5 & +.5 & 0 & -1 & +2 & -3 & +3 \\
\hline & & -0.062 & -.25 & +0.56 & +0.85 & +1 & -1.12 & +.46 & 0 & +.11 \\
\hline \multicolumn{2}{|l|}{ Results } & weak & weak & good & good & good & $\begin{array}{c}\text { Too } \\
\text { weak }\end{array}$ & good & weak & good \\
\hline
\end{tabular}

\section{Conclusion}

Each landscape caries unique feeling, concepts, and meaning that strengthen sense of place, and its identity and feeling of identity. Perception-based approaches in Landscape visual assessment can help the planners to discover those uniquely ecological and cultural memories of a space as well as saving time, energy and budget needed for executing an innovative and conceptual design. In addition, it can provide an opportunity to the public in project participation. The hard memorials may lose their holistic functions over time for the visitors, while the natural signs and green landscape elements existing in the site are more sustainable and dynamic and have their influence for a long time.

Even though evolving people and experts' perception in aesthetic landscape assessment has been discussed for a long time, there is no specific guideline about how actually the individuals can contribute in landscape perception studies. Evaluation of visual landscape may be extremely unique for a site according to the aim of its development and the people's characteristics like their ages, educations; however general strategies can be developed to get the people's perception about landscapes at primary steps of projects.

Understanding the concepts of landscape are partial that depends on the people's awareness of the concepts related to the event. In this research, the landscape indicators in landscape assessment were determined by the students studying in landscape architecture as they certainly have a better perception of the signs and symbols, compared to the public. However, it seems that a method which allows both opinion of the experts and the public combine together, will lead to reliable results.

\section{Acknowledgements}

This study is part of a master thesis, produced at the University of Tehran with the title of "The Sacred Defense Memorial Garden-Museum Design”. The thesis was accepted by Mayer of Tabriz in order to use it in designing a memorial garden in Tabriz. We thank Dr. Bahram Behzad, Department of Biological Sciences/Tehran, for providing the data on plants types and their attitudes.

\section{References}

Ahmadi, B., 1992. Visual Cues to the Text of the Semiotics of Visual Communication. Third ed. Tehran, Iran.

Fry, G., Tveit, M. S., Ode, A., Velarde, M. D., 2009. The ecology of visual landscapes: Exploring the conceptual common ground of visual and ecological landscape indicators. Ecological indicators, 9(5): 933-947.

Ghazizadeh, Kh., 2010. Art of the Islamic revolution in transition. Honarhaye Tajasomi magazine, 7: 16-20.

Gough, P., 2000. From Heroes' Groves to parks of peace: Landscapes of remembrance, protest and peace. Landscape Research, 25(2): 213-228.

Gobster, P.H., 1999. An ecological aesthetics for forest landscape management. Landscape, J. 18(1): 54-64.

Halali, F., Tahooni, R., 2006. Technical; social and cultural feasibility studies of the Cultural Center of Sacred Defense construction, Tabriz: Department of Preservation and Publication of Sacred Defense Works and Values (department of engineering), Iran.

Jessel, B., 2006. Elements, Characteristics and CharacterInformation Functions of Landscapes in term of Indicators. Ecological Indicators, 6:153-167.

Kaplan, R., Kaplan, S., 1989. The Experience of Nature: A Psychological Perspective. Cambridge University Press, Cambridge.

Lothian, A., 1999. Landscape and the philosophy of aesthetics: is landscape quality inherent in the landscape or in the eye of the beholder?. Landscape and Urban Planning, 44:177-198.

Nohl, W., 1980. Freiraumarchitektur and Emanzipation. Frankfurt, Bern, Cirencester.

Nohl, W., 2001. Sustainable landscape use and aesthetic perception - preliminary reflections on future landscape aesthetics. Landscape and Urban Planning, 54: 223-237.

Palangi, N., 2008. Memories of Khoramshahr. Tavoos magazine, 2: 40.

Pouya, S., 2011. The sacred defense Memorial gardenmuseum Design. Dissertation, University of Tehran, Iran.

Pouya, S., Behbahani, I., H., Pouya, S., 2014. The war memorial garden design. Arts and Design Studies, 26: 66-76. 
Rosley F. S. M., Lamit H., Long A., Yusryza W., Ibrahim, W., 2013. Review on methodology of visual aesthetic: Quality assessment in landscape planning, http://epublication.fab.utm.my/116/.

(Accessed: 01/10/2017)

Taghi Zadeh, A., A., Sangari, M., Abdolahi, M., 2008. Spiritual and Cultural Factors in the Sacred Defense (Islamic Research Institute). Zamzam H.publication, Qom, Iran.

Tveit, M., Ode, A., Fry, G., 2006. Key concepts in a framework for analysing visual landscape character. Landsc. Res., 31(3): 229-255.
Terry, C.D., 2001. Whither scenic beauty? Visual landscape quality assessment in the $21^{\text {st }}$ century. Landscape and Urban Planning, 54:267-281.

Wu, Y., Bishop, I., Hossain, H., Sposito, V., 2006. Using GIS in Landscape Visual Quality Assessment. Applied GIS, Monash University Epress.

Yung, C. G., 1980. Man and His Symbols. Paya publishing, Tehran.

Zube, E. H., 1982. An exploration of southwestern landscape images. Landscape Journal, 1: 31-40. 